\title{
BELAJAR TERHADAP HASIL BELAJAR IPS
}

\author{
Sinta Maria Dewi \\ PGSD FKIP UBP Karawang \\ Nailasinta09@gmail.com
}

\begin{abstract}
The objective of this research is to find out of the effect of learning media and self regulated learning toward the result of learning sosial science. The method used was experimental study design using treatment by level design $2 \times 2$. The research, findings show that: (1) as a whole that cd multimedia interactive is higher than presentation (2) theres is interaction between media and self regulated learning toward the result of learning social science (3) the result of learning cd multimedia interactive is higher than presentation which have the high of self regulated learning (4) the result of learning cd multimedia interactive is lower than the result presentation which have the low of self regulated learning.The implication of this study towards learning media is to increas the ability of the result of social science. The practical implication can be develop from the result of this study, not only for social science but also for other sebjects of study.
\end{abstract}

Keyword: Learning media, self regulated learning and the result of learning sosial science.

\begin{abstract}
Abstrak: Penelitian ini bertujuan untuk mengetahui Pengaruh Media Pembelajaran dan Kemandirian Belajar terhadap Hasil Belajar IPS siswa. Metode yang digunakan dalam penelitian ini adalah eksperimen dengan menggunakan desain treatment by level $2 \times 2$. Temuan penelitian ini menunjukkan bahwa: (1) Secara keseluruhan, media pembelajaran $C D$ interaktif lebih tinggi daripada pembelajaran menggunakan media presentasi. (2) Terdapat pengaruh interaksi antara media pembelajaran dan kemandirian belajar terhadap hasil belajar IPS. (3) Hasil belajar IPS melalui media cd interaktif lebih tinggi dari hasil belajar IPS melalui media presentasi untuk siswa yang memliki kemandirian belajar tinggi. (4) Hasil belajar IPS melalui media cd interaktif lebih rendah dari hasil belajar IPS melalui media presentasi untuk siswa yang memiliki kemandirian belajar rendah. Implikasi peneltian ini adalah perlu diadakan pembekalan bagi guru untuk meningkatkan pengetahuan baru dalam proses pembelajaran yang aktif kreatif dengan media pembelajaran yang menyenangkan.
\end{abstract}

Kata Kunci: media pembelajaran, kemandirian belajar dan hasil belajar IPS. 


\section{PENDAHULUAN}

Ilmu Sosial adalah suatu bahan kajian yang terpadu yang merupakan penyederhanaan, adaptasi, seleksi, dan modifikasi yang diorganisasikan dari konsep-konsep dan keterampilan Sejarah, Geografi, Sosiologi, Antropologi, dan Ekonomi. Selanjutnya, IPS merupakan salah satu mata pelajaran yang diberikan di Sekolah Dasar yang mengkaji seperangkat peristiwa, fakta, konsep, dan generalisasi yang berkaitan dengan isu sosial. Memuat materi geografi, sejarah, sosiologi, dan ekonomi. Melalui mata pelajaran IPS, anak diarahkan untuk dapat menajdi warga negara Indonesia yang demokratis, bertanggungjawab, serta warga dunia yang cinta damai.

Pembelajaran Ilmu Pengetahuan Sosial (IPS) di Sekolah Dasar harus memperhatikan kebutuhan anak yang berusia antara 6-12 tahun, anak dalam kelompok usia 7-11 tahun menurut Piaget 1963 (dalam Gunawan 2008:51) berada dalam perkembangan kemampuan intelektual/kognitifnya pada tingkatan kongkrit operasional.
Mereka memandang dunia dalam keseluruhan yang utuh, dan menganggap tahun yang akan datang sebagai waktu yang masih jauh. Dalam pembelajaran IPS berisikan dengan pesan-pesan yang berifat abstrak. Oleh karena itu, menurut Brunner 1978 (dalam Gunawan Rudy 2013:50) memberikan pemecahan berbentuk jembatan bailey untuk mengkongkritkan yang abstrak itu dengan enactive, iconic, dan symbolik melalui percontohan dengan gerak tubuh, gambar, bagan, peta, grafik, lambang, keterangan lanjut, atau elaborasi dalam kata-kata yang dipahami siswa.

Masalah yang ditemukan dalam kelas V SDN Pancawati II Karawang, proses pembelajaran IPS yang terjadi berpusat pada guru (teacher centered). Sehingga peserta didik kurang termotivasi dalam belajar IPS karena cara pembelajaran guru yang kurang menarik, tidak partisipatif dan tidak sesuai dengan kebutuhan masing-masing peserta didik. Dibawah ini adalah data nilai rata-rata siswa tahun pelajaran 2012-2013 yaitu: 
Tabel 1

Hasil Ujian Akhir Semester 2012-2013

\begin{tabular}{|l|c|c|c|c|c|c|}
\hline \multirow{2}{*}{} & \multicolumn{6}{|c|}{ Bidang Studi } \\
\cline { 2 - 7 } & PKN & BI & MTK & IPA & IPS & BING \\
\hline Rata-Rata & 80.5 & 80.2 & 80.7 & 80.8 & 78.1 & 84.1 \\
\hline KKM & 75 & 75 & 70 & 70 & 70 & 70 \\
\hline
\end{tabular}

Dari data diatas diperoleh bahwa nilai akhir semester mata pelajaran IPS masih rendah dibandingkan dengan mata pelajaran yang lain. Selanjutnya berdasarkan wawancara dengan guru kelas V bahwa nilai IPS rendah dikarenakan hampir semua materi pelajaran IPS berupa hapalan sehingga peserta didik kurang termotivasi dalam belajar IPS. Pembelajaran yang terkesan monoton mengakibatkan siswa merasa bosan dalam mempelajari materi khusunya materi yang berhubungan dengan sejarah. Berawal dari hal tersebut diperlukan pembelajaran dengan menggunakan media pembelajaran yang dapat menarik minat peserta didik, memenuhi kebutuhan masingmasing dan dapat berpartisipasi secara interaktif.

Untuk mengatasi hal tersebut, maka kita harus mulai berani beranjak menggeser paradigma pengajaran menuju paradigma pembelajaran yang berorientasi pada sumber belajar. Media menjadi salah satu sumber belajar yang diharapkan mampu memandirikan belajar siswa, sehingga guru berfungsi sebagai fasilitator. Agar pembelajaran IPS lebih bermakna bagi peserta didik untuk membentuk kepribadian yang dapat memecahkan segala permasalahan di masyarakat, mandiri dalam belajar, maka salah satu proses pembelajaran disekolah dasar hendaknya memulai dengan pembelajaran yang menarik dengan menggunakan media CD Interaktif. Seperti yang dijelaskan oleh Wijaya, Panama dan Erina dalam Gunawan Rudy (2013:191) menyebutkan bahwa media yang diminati responden dalam mempelajari sejarah adalah teks $(6,3 \%)$, gambar $(10,3 \%)$, animasi $(16,6 \%)$, video $(29,1 \%)$, game $(32,6 \%)$ dan lainnya $(5,1 \%)$. 
Untuk mencapai suatu keberhasilan dalam pembelajaran, kemandirian belajar merupakan salah satu faktor internal pada diri seseorang yang akan menimbulkan keyakinan untuk meraih hasil tertentu. Menurut Hugo Gaudig (dalam Herman Holsten, 1989:26) bahwa kemandirian selalu membantu proses belajar dengan mengaktifkan pengetahuan/pengertian pemantapan dan pengamanan yang telah dipelajari, maupun memberikan motivasi sehubungan dengan kesediaan belajar. Dengan demikian tujuan penelitian ini yaitu untuk mengetahui pengaruh media pembelajaran dan kemandirian belajar terhadap hasil belajar IPS.

\section{METODE PENELITIAN}

Metode yang digunakan dalam penelitian ini adalah metode eksperimen dengan menggunakan desain treatment by level $2 \times 2$. Dalam penelitian ini terdapat variabel bebas (variable predictor) yaitu media pembelajaran $\left(\mathrm{X}_{1}\right)$ dan variabel moderat yaitu kemandirian belajar $\left(\mathrm{X}_{2}\right)$ dan variabel terikat (variable criteria) yaitu hasil belajar IPS (Y).

Instrumen hasil belajar IPS dengan menggunakan tes tertulis, perangkat tes yang digunakan untuk mengukur hasil belajar ini berbentuk tes objektif, yaitu bentuk tes pilihan ganda dengan lima alternatif jawaban dan instrumen kemandirian belajar dengan menggunakan angket. Untuk pengujian normalitas data dilakukan dengan menggunakan Uji Liliefors dan uji homogenitas dengan Uji Barlett. Adapun teknik analisis data yang digunakan yaitu ANAVA dua jalur dan pengujian simple efferct dengan Uji Tuckey.

\section{HASIL PENELITIAN}

Rekapitulasi deskripsi data penelitian untuk masing-masing kelompok dapat dilihat sebagai berikut: 


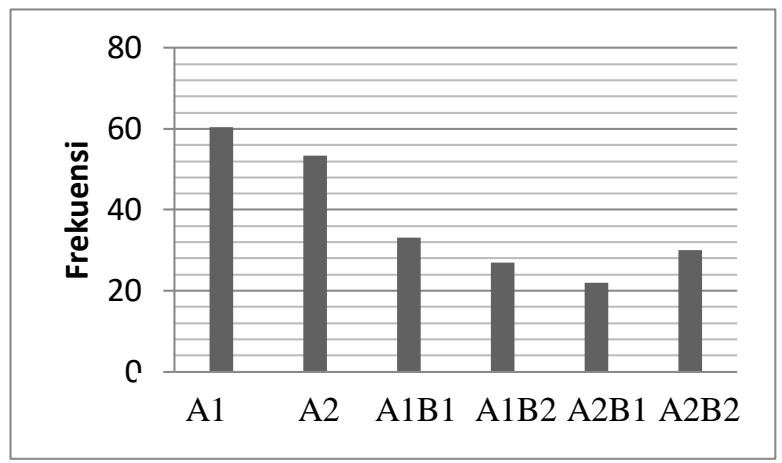

Gambar 1

Histogram Distribusi Frekuensi Skor Hasil Belajar IPS Menggunakan Media Pembelajaran Berdasarkan Kemandirian Belajar yang Dimiliki Siswa

Berdasarkan rekapitulasi data penelitian diatas, disimpulkan bahwa rata-rata $\mathrm{A}_{1}$ lebih tinggi daripada ratarata $\mathrm{A}_{2}$, untuk nilai rata-rata skor $\mathrm{A}_{1} \mathrm{~B}_{1}$ lebih tinggi daripada $\mathrm{A}_{1} \mathrm{~B}_{2}$ dan untuk nilai rata-rata skor $\mathrm{A}_{2} \mathrm{~B}_{2}$ lebih tinggi daripada nilai $\mathrm{A}_{2} \mathrm{~B}_{1}$.

Pengujian persyaratan analisis untuk uji hipotesis dakam penelitian ini mencakup uji normalitas data menggunakan uji Liliefors dan uji homogenitas dengan menggunakan uji Barlett. Berdasarkan data $\mathrm{A}_{1}, \mathrm{~A}_{2}$,
$\mathrm{A}_{1} \mathrm{~B}_{1}, \mathrm{~A}_{1} \mathrm{~B}_{2}, \mathrm{~A}_{2} \mathrm{~B}_{2}, \mathrm{~A}_{2} \mathrm{~B}_{1}$ dinyatakan normal dan homogen. Dengan demikian, berdasarkan kedua hasil pengujian persyaratan analisis dapat disimpulkan bahwa persyaratan yang diperlukan untuk analisis varians telah terpenuhi sehingga laya untuk dilakukan analisis lebih lanjut.

Untuk menguji hipotesis, terlebih dahulu dilakukan analisis varians dua jalur dengan interaksi (ANAVA 2x2). Hasil perhitungan ANAVA pada tabel 6 sebagai berikut: 
Tabel 2

Analisis Variansi untuk melihat Pengaruh Media Pembelajaran dan Kemandirian Belajar Siswa terhadap Hasil Belajar IPS

\begin{tabular}{|l|c|c|c|c|c|c|}
\hline \multirow{2}{*}{ Sumber Varians } & JK & Db & RJK & \multirow{2}{*}{ F $_{\text {hitung }}$} & \multicolumn{2}{|c|}{ F $_{\text {tabel }}$} \\
\cline { 6 - 8 } & 122,5 & 1 & 122,5 & $34,34579 * *$ & 4,11 & 7,39 \\
\hline $\begin{array}{l}\text { Media } \\
\text { (Antar A) }\end{array}$ & 16,9 & 1 & 16,9 & $4,738318^{*}$ & 4,11 & 7,39 \\
\hline $\begin{array}{l}\text { Kemandirian } \\
\text { Belajar } \\
\text { (Antar B) }\end{array}$ & 504,1 & 1 & 504,1 & $141,3364 * *$ & 4,11 & 7,39 \\
\hline Interaksi AxB & 128,4 & 36 & 3,5667 & & & \\
\hline Dalam & 771,9 & 39 & & & & \\
\hline Total & & & & & \\
\hline
\end{tabular}

*Signifikan

** Sangat Signifikan

Hipotesis Pertama, hasil perhitungan Anava menunjukkan bahwa hipotesis pertama diperoleh $\mathrm{F}_{\text {hit }}=34,345>\mathrm{F}_{\mathrm{tab}}=4,11$ pada taraf sifnifikan $\alpha=0,05$. Artinya rata-rata skor hasil belajar IPS siswa yang diajar dengan menggunakan media CD interaktif lebih tinggi daripada skor hasil belajar IPS siswa yang diajar dengan menggunakan media presentasi. Hal ini didukung oleh hasil uji Tukey yang menunjukkan nilai $\mathrm{Q}=8,5>$ nilai $\mathrm{Q}_{\mathrm{t}}=4,33$ untuk taraf signifikan $\dot{\alpha}=0,05$. Dengan demikian dapat disimpulkan bahwa terdapat perbedaan pengaruh yang signifikan antara media pembelajaran $\mathrm{CD}$ interaktif dengan media pembelajaran presentasi terhadap hasil belajar secara keseluruhan. Karena skor rata-rata hasil belajar IPS yang dihasilkan oleh media pemebelajaran $\mathrm{CD}$ interaktif lebih tinggi dibandingkan dengan hasil belajar IPS yang dihasilkan oleh media pembelajaran presentasi, maka secara keseluruhan disimpulkan bahwa media pembelajaran $\mathrm{CD}$ interaktif lebih baik dalam meningkatkan hasil belajar IPS bagi siswa yang menjadi subjek penelitian.

Menurut Rudi Susilana (2008:22) karakteristik dari CD multimedia interaktif ini adalah bahwa siswa tidak hanya memperhatikan media saja atau objek saja, melainkan juga dituntut untuk berinteraksi selama mengikuti 
pembelajaran. Pembelajaran dengan menggunakan media CD interaktif mampu memberikan iklim yang lebih bersifat afektif dengan cara belajar yang mandiri sehingga dapat memenuhi kebutuhan belajar siswa, memotivasi belajar, tidak pernah bosan dalam menggunakannya.

Dilain pihak, media pembelajaran yang digunakan yaitu media presentasi, media presentasi digunakan dalam pembelajaran secara klasikal berbeda dengan media CD interaktif yang secara mandiri atau kelompok kecil. Menurut Yudhi Munadi (2013:150) media presentasi digunakan untuk menjelaskan materimateri yang sifatnya teoritis digunakan dalam pembelajaran klasikal dengan group belajar yang cukup banyak diatas 50 orang dan penggunaan media ini sangat tergantung pada penyaji materi. Dalam pembelajaran disekolah, penggunaan media presentasi ini lebih banyak "guru" dan media ini lebih banyak digunakan untuk memperjelas materi yang ingin disampaikan guru kepada para "murid". Selain itu media pembelajaran ini kurang dapat memotivasi siswa dalam belajar, sehingga diswa dalam belajar menjadi mudah bosan yang sangat mempengaruhi hasil belajarnya.

Hipotesis Kedua, hasil perhitungan ANAVA diperoleh bahwa Fhitung $=141,3364$ lebih besar dari nilai $\mathrm{F}$ tabel $=4,11$ pada taraf signifikan $\dot{\alpha}=0,05$. Artinya, terdapat pengaruh interaksi yang sangat signifikan antara media pembelajaran dan kemandirian belajar terhadap hasil belajar IPS siswa. Adanya interaksi membuktikan bahwa media pembelajaran memberi pengaruh yang berbeda terhadap hasil belajar IPS jika diterapkan pada kelompok yang memiliki kemandirian belajar yang berbeda.

Media pembelajaran merupakan alat bantu yang sangat bermanfaat bagi para siswa dan pendidik dalam proses belajar mengajar. Schram (dalam Dina Indriani, 2011:14) menyatakan bahwa media merupakan teknologi pembawa pesan yang dapat dimanfaatkan untuk keperluan pembelajaran, sehingga media menjadi perluasan dari guru. Dengan adanya media pengajaran, peran guru 
menjadi semakin luas. Sedangkan anak didik akan terbantu untuk belajar dengan lebih baik, serta terangsang untuk memahami subjek yang tengah diajarkan dalam bentuk komunikasi penyampaian pesan yang lebih efektif dan efisien.

Kemandirian menurut Enung Fatimah (2010:149), meliputi "perilaku mampu berinisiatif, mampu mengatasi hambatan/masalah, mempunyai rasa percaya diri dan dapat melakukan sesuatu sendiri tanpa bantuan orang lain.”

Kemandirian belajar adalah aktivitas belajar yang dilakukan oleh individu dengan kebebasannya dalam menentukan dan mengolah sendiri bahan ajar, waktu, tempat dan memanfaatkan berbagai sumber belajar yang diperlukan. Dengan kebebasan tersebut, individu memiliki kemampuan dalam mengelola cara belajar, memiliki rasa tanggung jawab yang tinggi dan terampil memanfaatkan sumbersumber belajar.

Sementara itu, hasil belajar IPS siswa dipengaruhi oleh faktor ekstrenal dan internal. Faktor eksternal berasal dari guru, antara lain dengan pemilihan guru terhadap media pembelajarannya. Sedangkan faktor internal berasal dari diri siswa itu sendiri, antara lain kemandirian belajar. Bagi siswa yang mempunyai kemampuan belajar tinggi dengan media pembelajaran $\mathrm{CD}$ interaktif hasil belajarnya lebih tinggi daripada siswa yang belajar dengan media presentasi dan sebaliknya.

Berdasarkan hasil temuan penelitian dan kajian teori dapat disimpulkan bahwa terdapat interaksi yang sangat signifikan antara media pembelajaran dan kemandirian belajar terhadap hasil belajar IPS siswa SD kelas V.

Hipotesis Ketiga, hasil perhitungan menunjukkan bahwa uji Tukey, diperoleh nilai $\mathrm{Q}=12,88$ dan nilai $\mathrm{Qt}=4,33$ pada taraf signifikan $\dot{\alpha}=0,05$. Sehingga hasil pengujian memberikan kesimpulan bahwa hasil belajar IPS pada siswa yang diajar dengan $\mathrm{CD}$ interaktif lebih tinggi daripada siswa yang diajar dengan media presentasi dalam meningkatkan hasil belajar IPS bagi siswa yang memiliki kemandirian belajar tinggi. 
Menurut Benedicta (2009:19) menjelaskan bahwa seseorang yang mempunyai kemandirian, dia lebih senang bekerja sendiri, menentukan dan memilih cara kerja yang sesuai dengan kata hatinya. Dia mementingkan otonomi dalam bertindak, pengambilan keputusan, dan pemilihan berbagai kegiatan dalam mencapai tujuan. Siswa memiliki ciri ini akan lebih mudah menguasai materi pelajaran yang dipelajari dibandingkan siswa yang tidak memiliki ciri tersebut.

Menurut Rudi Susilana (2008:22) kemandirian belajar dihubungkan dengan media pembelajaran yang digunakan dalam proses belajar, maka sesuai dengan ciri utama multimedia Interaktif yang sesuai dengan namanya yaitu interaktif, multimedia ini diprogram atau dirancang untuk dipakai oleh siswa secara individual (belajar mandri) yang bertujuan membantu siswa menemukan makna dari apa yang telah dipelajari.

Karakteristik yang dimiliki oleh siswa yang kecenderungan memiliki kemandirian belajar memberi petunjuk bahwa media pembelajaran yang interaktif seperti CD interaktif akan lebih menguntungkan. Dilain pihak, media pembelajaran yang digunakan yaitu media presentasi, media presentasi digunakan dalam pembelajaran secara klasikal berbeda dengan media CD interaktif yang secara mandiri atau kelompok kecil. Penggunaan media presentasi ini lebih banyak "guru" dan media ini lebih banyak digunakan untuk memperjelas materi yang ingin disampaikan guru kepada para "murid"

Berdasarkan hasil temuan penelitian dan kajian teori dapat disimpulkan bahwa hasil belajar IPS siswa yang memiliki kemandirian belajar tinggi lebih baik jika menggunakan media pembelajaran CD interaktif daripada yang diajar dengan menggunakan media presentasi.

Hipotesis Keempat, hasil perhitungan dengan uji Tukey, diperoleh nilai $\mathrm{Q}_{\text {hitung }}=4,37>\mathrm{Q}_{\text {tabel }}=$ 4,33 pada taraf signifikan $\dot{\alpha}=0,05$. Sehingga hasil pengujian memberikan kesimpulan bahwa hasil belajar IPS pada siswa yang diajar dengan $\mathrm{CD}$ interaktif lebih rendah 
daripada siswa yang diajar dengan media presentasi dalam meningkatkan hasil belajar IPS bagi siswa yang memiliki kemandirian belajar rendah.

Reber (1985) (dalam Enung Fatimah 2010:149) menjelaskan bawa kemandirian adalah suatu sikap otonomi bahwa seseorang secara relatif bebas dari pengaruh penilain, pendapat, dan keyakinan orang lain. Dengan otonomi tersebut, seorang diharapakan akan lebih bertanggung jawab terhadap dirinya sendiri.

Jadi kemandirian belajar ini pada prinsipnya hanya akan sampai pada pemerolehan hasil belajar, mulai dari keterampilan, pengembangan, penalaran, pembentukan sikap sampai kepada penemuan diri sendiri, apabila ia mengalami sendiri dalam proses pemerolehan hasil belajar tersebut. Dimana siswa yang memiliki kemandirian belajar rendah mempunyai karakteristik harus selalu di dorong oleh orang lain untuk belajar.

Siswa yang memiliki kemandirian belajar rendah mengikuti proses pembelajaran apa adanya, sehingga diperlukan tujuan pembelajaran yang tersusun dengan baik. Struktur materi pembelajaran juga cenderung diikuti sesuai dengan yang disajikan, sehingga diperlukan materi pembelajaran yang terstruktur dengan baik dan sistemastis. Proses pembelajaran dengan media presentasi lebih menguntungkan bagi siswa yang memiliki kemandirian belajar rendah.

Siswa yang memiliki kemandirian belajar rendah cenderung untuk menerima struktur yang sudah ada, cenderung mengikuti tujuan yang yang sudah ada. Untuk pembelajaran dengan media $\mathrm{CD}$ interaktif bagi siswa yang memiliki kemandirian belajar rendah cenderung akan membuat pembelajaran tidak bermakna karena kurang menantang sehingga dapat menurunkan motivasi yang berakibat dapat menurunkan hasil belajar siswa. Keadaan ini tentunya dapat memberikan dampak terhadap pencapaian hasil belajar IPS.

Berdasarkan hasil temuan penelitian dan kajian teori dapat disimpulkan bahwa hasil belajar IPS siswa yang memiliki kemandirian belajar rendah lebih baik jika 
menggunakan media pembelajaran presentasi daripada yang diajar dengan menggunakan media $\mathrm{CD}$ interaktif.

\section{PENUTUP}

Berdasarkan hasil pengujian hipotesis dan pembahasan diperoleh kesimpulan yaitu: (1). Terdapat perbedaan hasil belajar IPS siswa antara siswa yang diajar dengan media pembelajaran $\mathrm{CD}$ interaktif dan siswa yang diajar dengan media pembelajaran presentasi. Pembelajaran dengan media pembelajaran $\quad \mathrm{CD}$ interaktif memberikan pemahaman yang lebih baik daripada pembelajaran dengan media pembelajaran presentasi. (2). Terdapat interaksi antara media pembelajaran dengan kemandirian belajar yang memberikan perbedaan pengaruh terhadap hasil belajar IPS. (3). Bagi siswa yang memiliki kemandirian belajar tinngi dan diajar dengan media pembelajaran $\mathrm{CD}$ interaktif memperoleh hasil belajar IPS yang lebih tinggi dibandingkan siswa yang diajar dengan media pembelajaran presentasi. (4). Bagi siswa yang memiliki kemandirian belajar rendah dan diajar dengan media pembelajaran $\mathrm{CD}$ interaktif memperoleh hasil belajar IPS lebih rendah dibandingkan siswa yang diajar dengan media pembelajaran presentasi.

Berdasarkan kesimpulan, diajukan saran yang dapat dipertimbangkan dalam peningkatan hasil belajar IPS siswa yaitu:

1. Sebaiknya guru lebih mampu menstimulasi dan melatih kemampuan dalam mengajarkan IPS dengan memberikan kebebasan seluas-luasnya kepada siswa untuk berekspresi dan mengambangkan potensi dirinya.

2. Pengembangan media pembelajaran yang berpusat pada siswa, hendaknya dilakukan dengan memperhatikan cara berpikir siswa, sehingga siswa mampu mengoptimalkan kemampuan diri serta mendukung proses menuju kematangan kemampuannya.

3. Diharapkan guru dapat membuat beragam latihan dan media pembelajaran yang sesuai dengan karakteristik siswa tanpa harus 
membedakan latar belakang status sosial ekonomi siswa.

4. Diharapkan guru mengoptimalkan sarana yang ada sebagai media dan alat pembelajaran dalam rangka meningkatkan hasil belajr IPS.

5. Orang tua diharapkan dapat memberikan pendidikan kepada anaknya untuk mampu meningkatkan kemampuan anak sesuai dengan tingkat perkembangan anak.

6. Membiasakan siswa untuk dapat berekspresi secara bebas dan bertanggungjawab dalam segala hal. Menyediakan media-media yang disukai siswa sebagai sarana untuk menyampaikan pandangan, dengan memperhatikan kemandirian belajar siswa.

\section{DAFTAR PUSTAKA}

Fatimah, Enung. (2010). Psikologi Perkembangan Perkembangan Peserta Didik. Bandung: Pustaka Setia.

Gunawan, Rudy. (2013). Pendidikan IPS Filosofi, Konsep, dan Aplikasi. Bandung: Alfabeta.

Hermann Holstein. (1986) Murid Belajar Mandiri Situasi Belajar Mandiri dalam Pelajaran Sekolah. Bandung: Remadja Karya CV Bandung.

Indriana, Dina. (2011) Ragam Alat Bantu Media Pengajaran. Jogjakarta: Diva Press. 
